Article

\title{
Formation of Unsymmetrical Trinuclear Metallamacrocycles Based on Two Different Cone Calix[4]arene Macrocyclic Rings
}

\author{
Mariia V. Kniazeva ${ }^{1}$, Alexander S. Ovsyannikov ${ }^{1, *}$, Daut R. Islamov ${ }^{2}$, Aida I. Samigullina ${ }^{1}$, \\ Aidar T. Gubaidullin ${ }^{1}\left(\mathbb{D}\right.$, Svetlana E. Solovieva ${ }^{2}$, Igor S. Antipin ${ }^{2}$ and Sylvie Ferlay ${ }^{3, *(1)}$ \\ 1 Arbuzov Institute of Organic and Physical Chemistry, FRC Kazan Scientific Center, Russian Academy \\ of Sciences, Arbuzova 8, Kazan 420088, Russia; maria-mary-25@mail.ru (M.V.K.); s_aida_88@mail.ru (A.I.S.); \\ aidar@iopc.ru (A.T.G.) \\ 2 Kazan Federal University, Kremlevskaya 18, Kazan 420008, Russia; daut1989@mail.ru (D.R.I.); \\ evgersol@yandex.ru (S.E.S.); iantipin54@yandex.ru (I.S.A.) \\ 3 Université de Strasbourg, CNRS, CMC UMR 7140, F-67000 Strasbourg, France \\ * Correspondence: osaalex2007@rambler.ru (A.S.O.); ferlay@unistra.fr (S.F.)
}

Received: 7 April 2020; Accepted: 23 April 2020; Published: 1 May 2020

check for updates

\begin{abstract}
A combination of tetrasulfonylcalix[4]arene (3-4H) together with a calix[4]arene dicarboxylate derivative $2-4 \mathrm{H}$ led, in the presence of $\mathrm{M}^{\mathrm{II}}\left(\mathrm{NO}_{3}\right)_{2}(\mathrm{M}=\mathrm{Co}, \mathrm{Ni}, \mathrm{Zn})$, to the formation of three novel isostructural metallomacrocycles of formula $\left[\mathrm{M}_{3}(\mathrm{DMF})_{2}\left(\mu_{3}-\mathrm{H}_{2} \mathrm{O}\right)-(2-2 \mathrm{H})-3\right]$. The structure of the prepared coordination compounds was studied in the solid state using single crystal/powder $\mathrm{X}$-ray diffraction studies. The X-ray diffraction on single crystal revealed that the structure of the obtained supramolecular complexes is composed of a trinuclear metallic cluster $\left[\mathrm{M}_{3}\right]^{+6}$ held between one di-deprotonated molecule of $(2-2 \mathrm{H})^{2-}$ offering two carboxylate groups for binding metal cations and one tetra-deprotonated compound $3^{4-}$, where four oxygen atoms, belonging to four deprotonated phenolic moieties and three oxygen atoms coming from three $\mathrm{SO}_{2}$ groups, are coordinated with the cluster core. Thus, an example of an easily reproducible molecular recognition pattern involving two different types of calix[4]arene based ligands, displaying different coordination moieties, and trinuclear metallic clusters, is reported here. In addition, it has been shown that the cone moieties of the calixarene also encapsulate solvent molecules.
\end{abstract}

Keywords: metallomacrocycle; tetrasulfonylcalix[4]arene; carboxylic derivatives of calix[4]arene; trinuclear clusters; coordination compounds

\section{Introduction}

In recent decades, metallamacrocyles, discrete complex supramolecular architectures, composed of polytopic ligands and metal ions, have attracted much attention because of their intriguing features [1-8]. Metallamacrocyles of different sizes and nuclearities have been reported, some of them presenting catalytic, magnetic, optical, redox or photophysical properties, essentially due to the presence of confined metal centers.

The investigation of the propensity of different molecular species to form metallamacrocyles has been of significant importance in the last decades. To date, in the literature, a series of recognition patterns based on the self-assembly of complementary organic ligands and metallic ions that allows to obtain hybrid discrete supramolecular species, among them, metallamacrocyles, have been well documented [9]. Concerning organic ligands, macrocycles generally present a well-adapted shape for the formation of metallamacrocyles: we can cite, for example, porphyrins, $[10,11]$ or calix[4]arenes. 
Calixarene $[12,13]$ is a family of versatile macrocyclic compounds that, when functionalized or not, are able to bind metallic cations, thus forming coordination compounds of various dimensionalities (0D-3D) that present attractive physical properties [14,15]. In particular, the calix[4]arenes cone conformers of $1-4 \mathrm{H}, 3-4 \mathrm{H}$ and $4-4 \mathrm{H}$ (Figure 1), are of interest because of their remarkable ability to form high-nuclearity metal complexes $[16,17]$, which can also be combined with auxiliary ligands to form metallomacrocycles.

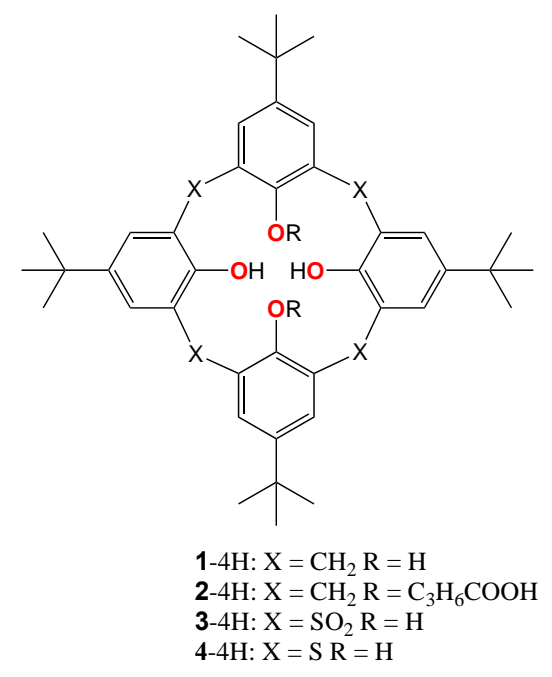

Figure 1. Classical p-tert-butylcalix[4]arene $(\mathbf{1}-4 \mathrm{H})$, the targeted macrocyclic ligand $(2-4 \mathrm{H})$, Tetrasulfonylcalix[4]arene $(3-4 \mathrm{H})$ and thiacalix[4]arene $(4-4 \mathrm{H})$.

In this aspect, the tetrasulfonylcalix[4]arene 3-4H [18,19], as shown in Figure 1, represents a very suitable polydentate ligand offering four phenolate groups together with four sulfonyl moieties as coordinating sites, to form metallomacrocycles as well as supramolecular capsules or cages when interacting with metallic cations [20]. The formation of supramolecular coordination compounds of highly nuclearities, based on its parent compound $4-4 \mathrm{H}$ has been recently documented [21-26].

It should be noted that metacyclophanes, a subclass of calix[4]arene compounds, have been reported as being able to form metallamacrocycles, using metallic cations like $\mathrm{Co}(\mathrm{II}), \mathrm{Cu}(\mathrm{II}), \mathrm{Zn}(\mathrm{II})$, $\mathrm{Hg}$ (II) and $\mathrm{Ag}(\mathrm{I})$ [27-30].

In this work, we present the synthesis and structure of a series of three isostructural coordination compounds that were obtained using two different types of macrocyclic ligands blocked in cone conformation, among them $3-4 \mathrm{H}$ (Figure 1) and another auxiliary macrocyclic ligand, a classical calixarene appended with two propoxycarbonyl-coordinating moieties, 2-4H [31]; both organic ligands are able to cap trinuclear clusters composed of $\mathrm{Co}(\mathrm{II}), \mathrm{Ni}(\mathrm{II})$ or $\mathrm{Zn}$ (II) cations.

Below, we focus on the formation of low-nuclearity compounds, like trinuclear species. Several examples of trinuclear metallamacrocycles based on different ligands have been documented in the literature, involving $\mathrm{Ni}$ (II) [32], $\mathrm{Pt}(\mathrm{II})$ and $\mathrm{Pd}(\mathrm{II})$ [33], $\mathrm{Fe}(\mathrm{II})$ [34], or $\mathrm{Ru}$ (II) [35], exhibiting some interesting magnetic or photoswitchable properties [36].

The structural analysis of the unprecedented unsymmetrical trinuclear metallamacrocycles, obtained using a strategy based on interaction between two different types of calix[4]arene ligands with metallic ions, will be presented in detail. To the best of our knowledge, the examples presented below are the first reported trinuclear metallomacrocycles based on the cooperative association of two different calix[4]arene ligands. 


\section{Materials and Methods}

\subsection{Materials}

2-4H [37,38] and Tetrasulphonylcalix[4]arene 3-4H [18] were synthesized following already described procedures. All solvents and reagents used in the synthesis were of analytical grade and used without further purification. Nitrate salts of cobalt (II), nickel (II) and Zinc (II) were obtained from commercial sources.

\subsection{Synthesis of $\mathrm{Co}_{3}\left(\mathrm{H}_{2} \mathrm{O}\right)(\mathrm{DMF})_{2}-(2-2 \mathrm{H})-3$}

Compounds 2-4H (25 mg, 29,4 mmol), 3-4H (24 mg, 29,4 mmol) together with $\mathrm{Co}\left(\mathrm{NO}_{3}\right)_{2} \cdot 6 \mathrm{H}_{2} \mathrm{O}$ (43 mg, $148 \mathrm{mmol}$ ) were dissolved in DMF/MeOH mixture $(2 / 1,9 \mathrm{~mL})$ and put into a Pyrex crystallization reactor equipped with a screw cap. Then, the solution was heated under MW irradiation conditions $(100 \mathrm{~W})$ and stirred for 3 hours. After cooling and filtration, pink single crystals suitable for X-ray diffraction were obtained upon slow evaporation of the mother liquor at room temperature under aerobic conditions for 1 week. Total yield: $35 \mathrm{mg}(44 \%)$.

Anal. Found for $\left(\mathrm{C}_{40} \mathrm{H}_{44} \mathrm{O}_{12} \mathrm{~S}_{4}\right)\left(\mathrm{C}_{52} \mathrm{H}_{66} \mathrm{O}_{8}\right) \mathrm{Co}_{3}\left(\mathrm{C}_{3} \mathrm{H}_{7} \mathrm{NO}\right)_{2}\left(\mathrm{H}_{2} \mathrm{O}\right) \cdot\left(\mathrm{C}_{3} \mathrm{H}_{7} \mathrm{NO}\right)_{5}\left(\mathrm{H}_{2} \mathrm{O}\right)_{2}: \mathrm{C}, 56.40$; $\mathrm{H}, 6.91 ; \mathrm{N}, 4.07$; S, 5.33\%. Calc.: C, 56.92; H, 6.93; N, 4.80; S, $5.17 \%$.

\subsection{Synthesis of $\mathrm{Ni}_{3}\left(\mathrm{H}_{2} \mathrm{O}\right)(\mathrm{DMF})_{2}-(2-2 \mathrm{H})-3$}

The green single-crystals of $\mathrm{Ni}_{3}\left(\mathrm{H}_{2} \mathrm{O}\right)(\mathrm{DMF})_{2}-2-3$ were obtained by following similar crystallization conditions described for $\mathrm{Co}_{3}\left(\mathrm{H}_{2} \mathrm{O}\right)(\mathrm{DMF})_{2}-(2-2 \mathrm{H})-3$, using $\mathrm{Ni}\left(\mathrm{NO}_{3}\right)_{2} \cdot 6 \mathrm{H}_{2} \mathrm{O}$. Total yield: $40 \mathrm{mg}(51 \%)$.

Anal. Found for $\left(\mathrm{C}_{40} \mathrm{H}_{44} \mathrm{O}_{12} \mathrm{~S}_{4}\right)\left(\mathrm{C}_{52} \mathrm{H}_{66} \mathrm{O}_{8}\right) \mathrm{Ni}_{3}\left(\mathrm{C}_{3} \mathrm{H}_{7} \mathrm{NO}\right)_{2}\left(\mathrm{H}_{2} \mathrm{O}\right) \cdot\left(\mathrm{C}_{3} \mathrm{H}_{7} \mathrm{NO}\right)_{5}\left(\mathrm{H}_{2} \mathrm{O}\right): \mathrm{C}$, 56.84; $\mathrm{H}, 6.88 ; \mathrm{N}, 4.11 ; \mathrm{S}, 5.37 \%$. Calc. C, 56.92; H, 6.97; N, 4.80; S, $5.17 \%$.

\subsection{Synthesis of $\mathrm{Zn}_{3}\left(\mathrm{H}_{2} \mathrm{O}\right)(\mathrm{DMF})_{2}-(2-2 \mathrm{H})-3$}

The colorless single crystals of $\mathrm{Zn}_{3}\left(\mathrm{H}_{2} \mathrm{O}\right)(\mathrm{DMF})_{2}-2-3$ were obtained by following the similar crystallization conditions as described for $\mathrm{Co}_{3}\left(\mathrm{H}_{2} \mathrm{O}\right)(\mathrm{DMF})_{2}-(2-2 \mathrm{H})-3$, using $\mathrm{Zn}\left(\mathrm{NO}_{3}\right)_{2} \bullet 6 \mathrm{H}_{2} \mathrm{O}$. Total yield: $48 \mathrm{mg}(61 \%)$.

Anal. Found for $\left(\mathrm{C}_{40} \mathrm{H}_{44} \mathrm{O}_{12} \mathrm{~S}_{4}\right)\left(\mathrm{C}_{52} \mathrm{H}_{66} \mathrm{O}_{8}\right) \mathrm{Zn}_{3}\left(\mathrm{C}_{3} \mathrm{H}_{7} \mathrm{NO}\right)_{2}\left(\mathrm{H}_{2} \mathrm{O}\right) \cdot\left(\mathrm{C}_{3} \mathrm{H}_{7} \mathrm{NO}\right)_{5}\left(\mathrm{H}_{2} \mathrm{O}\right)_{2}$ : C, 55.53 ; H, 6.89; N, 4.01; S, 5.25\%. Calc.: C, 56.25; H, 6.93; N, 4.75; S, 5.11\%.

\subsection{Physical Measurements}

Elemental analysis was performed on a Vario Macro CHN Analyzer (Elementar Analysensysteme GmbH, Langenselbold, Germany).

\subsection{Single Crystal X-Ray Diffraction Studies}

Data sets for single crystals $\mathrm{M}_{3}(\mathrm{DMF})_{2}-2-3(\mathrm{M}=\mathrm{Co}, \mathrm{Ni}$ and $\mathrm{Zn})$ were collected on a Rigaku XtaLab Synergy $\mathrm{S}$ instrument with a HyPix detector and a PhotonJet microfocus $\mathrm{X}$-ray tube using $\mathrm{Cu}$ $\mathrm{K} \alpha(1.54184 \AA)$ radiation at $100 \mathrm{~K}$. Images were indexed and integrated using the CrysAlisPro data reduction package. Data were corrected for systematic errors and absorption using the ABSPACK module. The GRAL module was used for the analysis of systematic absences and space group determination. Using Olex2 [39], the structure was solved by direct methods with SHELXT [40] and refined by the full-matrix least-squares on $\mathrm{F}^{2}$ using SHELXL [41]. Non-hydrogen atoms were refined anisotropically. The figures were generated using the Mercury 4.1 program [42]. Disordered fragments were refined with reasonable constraints and restraints. DMF molecules were placed using lia's fragment library [43]. For $\mathrm{Zn}_{3}(\mathrm{DMF})_{2}-2-3$ a solvent mask was calculated and 15 electrons were found in a volume of $135 \AA^{3}$ in five voids per unit cell. This is consistent with the presence of $0.5 \mathrm{H}_{2} \mathrm{O}$ per unit cell. Crystal data are summarized in the crystallographic table (Table 1). 
Table 1. Crystallographic data for $\mathrm{Co}_{3}(\mathrm{DMF})_{2}-2-3, \mathrm{Ni}_{3}(\mathrm{DMF})_{2}-\mathbf{2 - 3}$ and $\mathrm{Zn}_{3}(\mathrm{DMF})_{2}-\mathbf{2 - 3}$.

\begin{tabular}{|c|c|c|c|}
\hline & $\mathrm{Co}_{3}\left(\mathrm{H}_{2} \mathrm{O}\right)(\mathrm{DMF})_{2}-(2-2 \mathrm{H})-3$ & $\mathrm{Ni}_{3}\left(\mathrm{H}_{2} \mathrm{O}\right)(\mathrm{DMF})_{2}-(2-2 \mathrm{H})-3$ & $\mathrm{Zn}_{3}\left(\mathrm{H}_{2} \mathrm{O}\right)(\mathrm{DMF})_{2}-(2-2 \mathrm{H})-3$ \\
\hline Formula & $\begin{array}{c}\mathrm{C}_{98} \mathrm{H}_{125} \mathrm{Co}_{3} \mathrm{~N}_{2} \mathrm{O}_{23} \mathrm{~S}_{4} \\
6.5\left(\mathrm{C}_{3} \mathrm{H}_{7} \mathrm{NO}\right)\end{array}$ & $\begin{array}{c}\mathrm{C}_{98} \mathrm{H}_{126} \mathrm{~N}_{2} \mathrm{Ni}_{3} \mathrm{O}_{23} \mathrm{~S}_{4} \\
6.5\left(\mathrm{C}_{3} \mathrm{H}_{7} \mathrm{NO}\right)\end{array}$ & 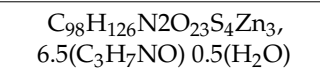 \\
\hline Molecular weight & 2479.14 & 2479.49 & 2508.48 \\
\hline Crystal System & Triclinic & Triclinic & Triclinic \\
\hline Space Group & $\mathrm{P} \overline{1}$ & $P \overline{1}$ & $\mathrm{P} \overline{1}$ \\
\hline a $(\AA ̊)$ & $13.0582(2)$ & $13.1486(3)$ & $13.12500(10)$ \\
\hline $\mathrm{b}(\AA)$ & $22.3247(3)$ & $22.2435(5)$ & $22.4394(2)$ \\
\hline c $(\AA)$ & $22.6890(3)$ & $22.6199(3)$ & $22.5845(2)$ \\
\hline$\alpha()$ & $76.5080(10)$ & $76.6746(14)$ & $76.5670(10)$ \\
\hline$\beta()$ & $79.8350(10)$ & $79.6798(13)$ & $79.7540(10)$ \\
\hline$\gamma()$ & $78.3650(10)$ & 77.9782(17) & $78.0450(10)$ \\
\hline $\mathrm{V}\left(\AA^{3}\right)$ & $6241.17(16)$ & $6236.3(2)$ & $6270.11(10)$ \\
\hline $\mathrm{Z}$ & 2 & 2 & 2 \\
\hline Color & Pink & Pale green & Colorless \\
\hline Crystal $\operatorname{dim}\left(\mathrm{mm}^{3}\right)$ & $0.258 \times 0.186 \times 0.084$ & $0.426 \times 0.393 \times 0.117$ & $0.426 \times 0.393 \times 0.117$ \\
\hline $\mathrm{D}\left(\mathrm{g} / \mathrm{cm}^{3}\right)$ & 1.319 & 1.320 & 1.329 \\
\hline $\mathrm{F}(000)$ & 2632 & 2640 & 2662 \\
\hline$\mu\left(\mathrm{mm}^{-1}\right)$ & 4.332 & 1.773 & 1.914 \\
\hline Wavelength $(\AA)$ & 1.54184 & 1.54184 & 1.54184 \\
\hline Number of data meas. & 198262 & 75586 & 213361 \\
\hline $\begin{array}{c}\text { Number of data with } \mathrm{I}> \\
2 \sigma(\mathrm{I})\end{array}$ & 25040 & $5524[\mathrm{R}(\mathrm{int})=0.0347]$ & $8993[\mathrm{R}(\mathrm{int})=0.0297]$ \\
\hline $\mathrm{R}$ & 0.0867 & 0.0714 & 0.0731 \\
\hline $\mathrm{Rw}$ & 0.0950 & 0.0864 & 0.0793 \\
\hline GOF & 1.086 & 1.022 & 1.016 \\
\hline $\begin{array}{l}\text { Largest peak in final } \\
\text { difference }\left(\mathrm{e}^{\circ} \AA^{-3}\right)\end{array}$ & -1.335 and 1.833 & -0.940 and 1.533 & -1.077 and 0.107 \\
\hline
\end{tabular}

CCDC 1989778, 1989779 and 1989780 contain the supplementary crystallographic data for $\mathrm{Co}_{3}\left(\mathrm{H}_{2} \mathrm{O}\right)(\mathrm{DMF})_{2}-(2-2 \mathrm{H})-3, \mathrm{Ni}_{3}\left(\mathrm{H}_{2} \mathrm{O}\right)(\mathrm{DMF})_{2}-(2-2 \mathrm{H})-3$ and $\mathrm{Zn}_{3}\left(\mathrm{H}_{2} \mathrm{O}\right)(\mathrm{DMF})_{2}-(2-2 \mathrm{H})-3$, respectively. These data are available for free from The Cambridge Crystallographic Data Base [44].

\subsection{X-Ray Diffraction on Powder}

Powder diffraction studies (PXRD) diagrams were collected on polycrystalline samples, on a Bruker D8 diffractometer using monochromatic $\mathrm{Cu}-\mathrm{K} \alpha$ radiation with a scanning range between $3.8^{\circ}$ and $40^{\circ}$ at a scan step size of $2^{\circ} \mathrm{min}^{-1}$. As already demonstrated and currently admitted, for all compounds, discrepancies in intensity between the observed and simulated patterns are due to the preferential orientations of the microcrystalline powders.

\section{Results and Discussion}

\subsection{Synthesis of the Trinuclear Complexes}

The coordination compounds $\mathrm{M}_{3}\left(\mathrm{H}_{2} \mathrm{O}\right)(\mathrm{DMF})_{2}-(2-2 \mathrm{H})-3(\mathrm{M}=\mathrm{Co}$, Ni and $\mathrm{Zn})$ were obtained using solvothermal conditions, followed by a slow evaporation of the solvents at room temperature under aerobic conditions (see experimental section).

The three compounds are isomorphous, isometric (see Table 1) and thus isostructural.

This synthesis was found to be reproducible, independent on the nature of the starting metallic salts $\mathrm{M}\left(\mathrm{NO}_{3}\right)_{2} \cdot 6 \mathrm{H}_{2} \mathrm{O}(\mathrm{M}=\mathrm{Co}$, Ni and $\mathrm{Zn})$. The obtained trinuclear species represent the thermodynamically stable compounds for this type of reaction.

\subsection{Description of the Strutcure of the Trinuclear Complexes}

Solvothermal synthesis in DMF/MeOH solution (2/1) between ligands 2-4H, 3-4H and $\mathrm{M}^{\mathrm{II}}\left(\mathrm{NO}_{3}\right)_{2}$ $\left(\mathrm{H}_{2} \mathrm{O}\right)_{6}(\mathrm{M}=\mathrm{Co}, \mathrm{Ni}$ and $\mathrm{Zn})$ in excess of metal salts, followed by the slow evaporation of the mother liquor, produced single crystals suitable for X-ray diffraction, which revealed the formation of isostructural trinuclear complexes $\mathrm{M}_{3}\left(\mathrm{H}_{2} \mathrm{O}\right)(\mathrm{DMF})_{2}-(2-2 \mathrm{H})-3(\mathrm{M}=\mathrm{Co}, \mathrm{Ni}$ and $\mathrm{Zn}$ ) (see Figure 2a,b) in the crystalline phase. It was established that crystals of $\mathrm{M}_{3}\left(\mathrm{H}_{2} \mathrm{O}\right)(\mathrm{DMF})_{2}-(2-2 \mathrm{H})-3$ (triclinic, space group 
$\mathrm{P} \overline{1}$ as shown in the crystallographic Table 1) present solvates: DMF molecules for Co and Ni-based compounds and DMF both with water molecules for the Zn-based analogue.

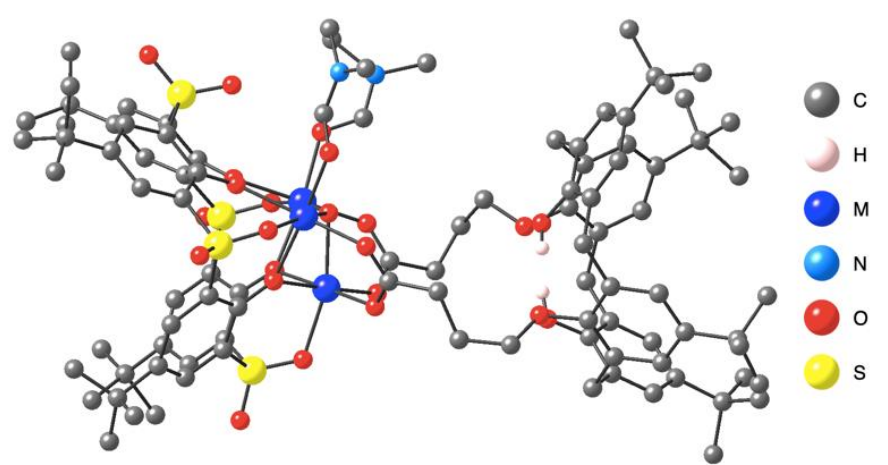

a

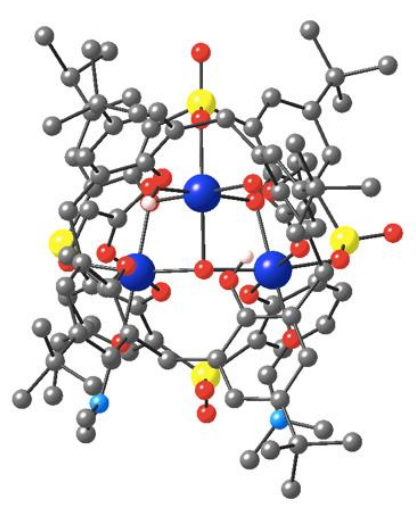

b

Figure 2. For $\mathrm{M}_{3}\left(\mathrm{H}_{2} \mathrm{O}\right)(\mathrm{DMF})_{2}-(2-2 \mathrm{H})-3\left(\mathrm{M}=\mathrm{Co}^{\mathrm{II}}, \mathrm{Ni}^{\mathrm{II}}\right.$ and $\left.\mathrm{Zn}^{\mathrm{II}}\right)$ : view of the formed trinuclear complex, (a) along the $b$ axis and (b) in the $\mathrm{xOz}$ plane. $\mathrm{H}$ atoms (excepting the protonated phenolic $\mathrm{O}$ atoms of 2-2 $\mathrm{H}^{2-}$ ) and solvent molecules (excepting coordinated DMF molecules) are omitted for clarity. For bond distances and angles see the text and Table 2. Disordered fragments are not represented.

Crystals of $\mathrm{M}_{3}(\mathrm{DMF})_{2}\left(\mathrm{H}_{2} \mathrm{O}\right)-2-3$ are composed of deprotonated ligands $(2-2 \mathrm{H})^{2-}$ and $3^{4-}$, three crystallographically independent metallic atoms, forming a trinuclear metallic cluster core, two coordinated DMF molecules and one $\mu_{3}$-water molecule. In addition, for all the compounds, 4.5 free-solvent DMF molecules and also, in the case of $\mathrm{Zn}_{3}\left(\mathrm{H}_{2} \mathrm{O}\right)(\mathrm{DMF})_{2}-(2-2 \mathrm{H})-3,0.5$ water molecules are present in the crystalline lattice.

For $\mathrm{Ni}_{3}\left(\mathrm{H}_{2} \mathrm{O}\right)(\mathrm{DMF})_{2}-(2-2 \mathrm{H})-3$ and $\mathrm{Zn}_{3}\left(\mathrm{H}_{2} \mathrm{O}\right)(\mathrm{DMF})_{2}-(2-2 \mathrm{H})-3$, one of two carboxylate moieties of $(2-2 \mathrm{H})^{2-}$, as well as one of the coordinated DMF molecules and some of the tertiobutyl groups belonging to $(2-2 \mathrm{H})^{2-}$ and $3^{4-}$ are found to be disordered. In addition, the free DMF molecules are also disordered in the lattice.

As was already mentioned, ligand $(2-2 \mathrm{H})^{2-}$ is double negatively charged due to two deprotonated carboxylate groups located on the alkyl substituents, which is demonstrated by the C-O distances, as shown in Table 2, whereas two phenolic moieties of the calixarene platform remain protonated. In contrast, for ligand $3^{4-}$, all phenolic $\mathrm{OH}$ groups are found to be deprotonated, leading to an overall charge of $4^{-}$. Analyses of the bond lengths and charge balance suggest that all of the metallic ions in the complexes are $\mathrm{M}^{\mathrm{II}}$.

Three crystallographically independent metallic cations are all in a deformed octahedral O6 environment, as shown in Figures 2a and 3a. The bonds are provided in Table 2. M1 and M3 are surrounded by six O-atoms, among them three belong to $3^{4-}$ : two O-atoms come from phenolate groups, with one $\mathrm{O}$-atom coming from sulfonyl moieties. It is also surrounded by one oxygen atom from a bridging carboxylate moiety of $(2-2 \mathrm{H})^{2-}$, one oxygen from a coordinated DMF molecule and one $\mu_{3}$-O-atom from a coordinated water molecule located in the middle of the triangle. M2 is surrounded by three atoms from $3^{4-}$ : two O-atoms from phenolate moieties, one O-atom from sulfonyl moieties, then two $\mathrm{O}$-atoms from the bridging carboxylate moieties of $(2-2 \mathrm{H})^{2-}$ and one $\mu_{3}-\mathrm{O}$ atom from the coordinated water molecule. The $\mathrm{M}-\mathrm{O}$ distances (metal to $\mathrm{O}$ from $3^{4-}$ phenolate, and from $(2-2 \mathrm{H})^{2-}$ carboxylate) are in the 1.9577 (312) to 2.2470 (30) $\AA$ range (see Table 2). The +2 charge of the metallic ions is confirmed by the $\mathrm{M}-\mathrm{O}$ distances found in the three complexes. 


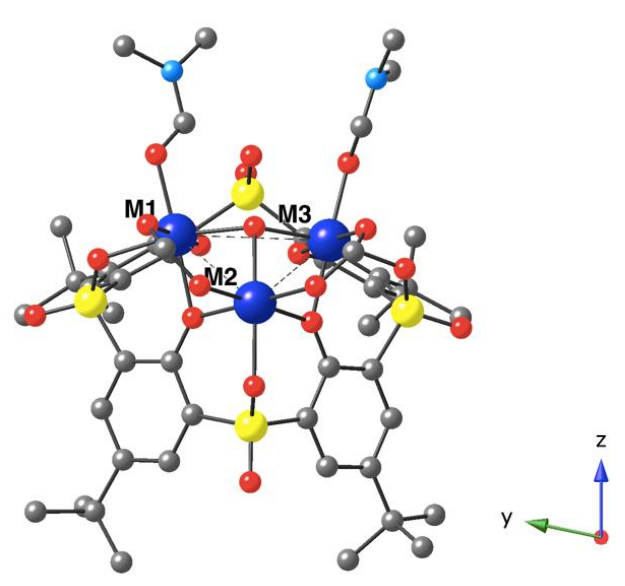

a

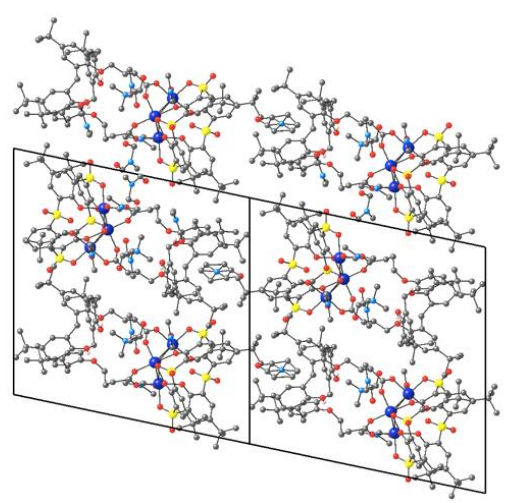

b

Figure 3. For $\mathrm{M}_{3}\left(\mathrm{H}_{2} \mathrm{O}\right)(\mathrm{DMF})_{2}-(2-2 \mathrm{H})-3\left(\mathrm{M}=\mathrm{Co}^{\mathrm{II}}, \mathrm{Ni}^{\mathrm{II}}\right.$ and $\left.\mathrm{Zn}^{\mathrm{II}}\right)$ : (a) view of the environment of the metallic cluster, and (b). view of the packing in the $\mathrm{yOz}$ plane. $\mathrm{H}$ atoms (except for the protonated phenol $\mathrm{O}$ atoms of $(2-2 \mathrm{H})^{2-} \mu_{3}-\mathrm{O}$ from the coordinated water molecule) and solvent molecules (except for coordinated DMF molecules) are omitted for clarity

The complex displays a "non-tubular" feature, where the fusion of both cone cavities is ensured by the trinuclear species, as shown in Figure 2b, which blocks the pathway from one cavity to another.

For the triangles formed by the trimetallic units, there are two short M-M distances and one long M-M distance (see Table 2), which confirms the presence of a water molecule in the middle of the non-isosceles triangle: 2.9380 (24) to 2.9919 (22) $\mathrm{A}$ for the shortest one and from 3.7823 (23) to 3.8214 (16) ̊ for the longest one. The MMM angles are also provided in Table 2.

In the unit cell, the metallic complexes are parallelly stacked along the $a$ and $b$ axes, as shown in Figure $3 b$. Disordered DMF molecules are encapsulated in the cavities formed by cone ligands $(2-2 \mathrm{H})^{2-}$ and $3^{4-}$ by van der Waals interactions, as shown in Figure 4. For $\mathrm{Zn}_{3}\left(\mathrm{H}_{2} \mathrm{O}\right)(\mathrm{DMF})_{2}-(2-2 \mathrm{H})-3$, water molecules are present with O-O distances of 2.6687 (140) and 3.1517 (169) $\AA$, demonstrating the hydrogen bonds between $\mathrm{H}_{2} \mathrm{O}$ and DMF molecules. There are no specific interactions between the isolated discrete trinuclear species.

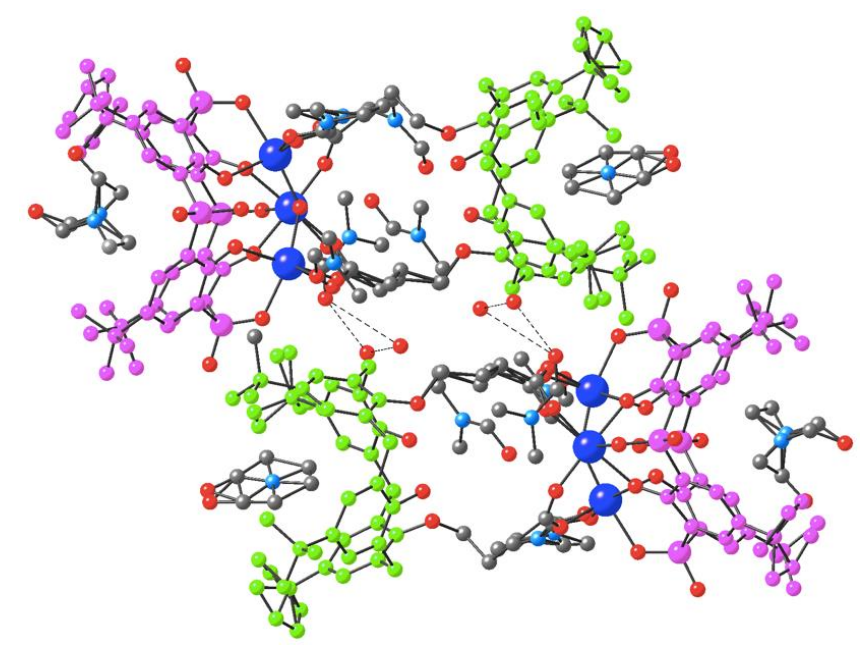

Figure 4. For $\mathrm{Zn}_{3}\left(\mathrm{H}_{2} \mathrm{O}\right)(\mathrm{DMF})_{2}-(2-2 \mathrm{H})-3\left(\mathrm{M}=\mathrm{Co}^{\mathrm{II}}, \mathrm{Ni}^{\mathrm{II}}\right.$ and $\left.\mathrm{Zn}^{\mathrm{II}}\right)$, view of the DMF crystal molecules encapsulated in the cones of $(2-2 \mathrm{H})^{2-}$ (green) and $3^{4-}$ (pink) and the water molecules lying between the clusters. 
Table 2. The main distances for $\mathrm{M}_{3}\left(\mathrm{H}_{2} \mathrm{O}\right)(\mathrm{DMF})_{2}-(2-2 \mathrm{H})-3\left(\mathrm{M}=\mathrm{Co}^{\mathrm{II}}, \mathrm{Ni}^{\mathrm{II}}\right.$ and $\left.\mathrm{Zn}^{\mathrm{II}}\right)$ clusters.

\begin{tabular}{|c|c|c|c|}
\hline & $\mathrm{Co}_{3}\left(\mathrm{H}_{2} \mathrm{O}\right)(\mathrm{DMF})_{2}-(2-2 \mathrm{H})-3$ & $\mathrm{Ni}_{3}\left(\mathrm{H}_{2} \mathrm{O}\right)(\mathrm{DMF})_{2}-(2-2 \mathrm{H})-3$ & $\mathrm{Zn}_{3}\left(\mathrm{H}_{2} \mathrm{O}\right)(\mathrm{DMF})_{2}-(2-2 \mathrm{H})-3$ \\
\hline \multirow{15}{*}{$\mathrm{M}-\mathrm{O}$} & $2.0097(30)$ & $1.9917(546)$ & $1.9538(313)$ \\
\hline & $2.0236(36)$ & 1.9956 (272) & $2.0064(29)$ \\
\hline & $2.0623(34)$ & $1.9994(29)$ & $2.0358(271)$ \\
\hline & $2.0755(30)$ & $2.0227(28)$ & 2.0376 (258) \\
\hline & 2.0775 (29) & $2.0129(515)$ & $2.0543(28)$ \\
\hline & $2.0844(29)$ & $2.0341(30)$ & $2.0712(276)$ \\
\hline & 2.0924 (32) & $2.0395(240)$ & 2.0891 (29) \\
\hline & $2.0999(27)$ & $2.0479(31)$ & $2.1058(30)$ \\
\hline & $2.1077(30)$ & $2.0534(29)$ & $2.1065(32)$ \\
\hline & $2.1081(31)$ & $2.0689(30)$ & $2.1090(28)$ \\
\hline & 2.1159 (29) & $2.0729(29)$ & $2.1411(29)$ \\
\hline & 2.1446 (29) & 2.0759 (29) & $2.1458(31)$ \\
\hline & $2.1832(29)$ & $2.0881(27)$ & $2.1733(32)$ \\
\hline & & 2.1039 (29) & $2.1733(26)$ \\
\hline & & 2.1280 (31) & $2.2480(30)$ \\
\hline \multirow{3}{*}{$\mathrm{M}-\mathrm{O}_{\mu 3 \text { water }}$} & $2.0172(28)$ & $2.0127(28)$ & $2.0169(28)$ \\
\hline & $2.0332(28)$ & $2.0237(26)$ & $2.0324(30)$ \\
\hline & $2.1201(28)$ & 2.0469 (28) & $2.0712(27)$ \\
\hline \multirow{3}{*}{$\mathrm{M}-\mathrm{O}_{\mathrm{DMF}}$} & $20335(57)$ & $1.9964(106)$ & $1.9954(87)$ \\
\hline & $2.0335(57)$ & 2.0204 (154) & $2.0352(31)$ \\
\hline & $2.0597(31)$ & $2.0223(31)$ & $2.0471(153)$ \\
\hline \multirow{3}{*}{ M-M } & 2.9890 (19) & $2.9380(24)$ & $2.9886(18)$ \\
\hline & $2.9919(22)$ & $2.9436(30)$ & $2.9914(21)$ \\
\hline & 3.7839 (18) & $3.7823(23)$ & $3.8214(16)$ \\
\hline \multirow{3}{*}{$\begin{array}{c}\text { MMM } \\
\text { Angle }\left(^{\circ}\right)\end{array}$} & 50.720 & 49.913 & 50.249 \\
\hline & 50.787 & 50.044 & 50.313 \\
\hline & 78.493 & 80.044 & 79.439 \\
\hline \multirow{6}{*}{$\mathrm{C}-\mathrm{O}$ (carboxylate) } & & (1.2115 (550) & $(1.2697(486)$ \\
\hline & (1.2517 (44) & 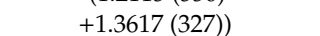 & $+1.2918(412))$ \\
\hline & $+1.2704(47))$ & (1.2413 (289) & (1.2609 (432) \\
\hline & $(1.2578(64)$ & $\begin{array}{r}+1.3037(540)) \\
\end{array}$ & +1.3050 (325)) \\
\hline & $+1.2602(56))$ & $(1.2608(44)+$ & $(1.2622(47)$ \\
\hline & & $1.2646(43))$ & $+1.2646(45))$ \\
\hline
\end{tabular}

The purity of the $\mathrm{M}_{3}\left(\mathrm{H}_{2} \mathrm{O}\right)(\mathrm{DMF})_{2}-(2-2 \mathrm{H})-3\left(\mathrm{M}=\mathrm{Co}^{\mathrm{II}}, \mathrm{Ni}^{\mathrm{II}}\right.$ and $\left.\mathrm{Zn}^{\mathrm{II}}\right)$ polycrystalline samples was investigated by PXRD on microcrystalline powders (see Figure 5). For all the compounds, a good match between the observed and calculated patterns from the XRD data was observed, attesting a pure crystalline phase for each $\mathrm{M}_{3}\left(\mathrm{H}_{2} \mathrm{O}\right)(\mathrm{DMF})_{2}-(2-2 \mathrm{H})-3\left(\mathrm{M}=\mathrm{Co}^{\mathrm{II}}, \mathrm{Ni}^{\mathrm{II}}\right.$ and $\left.\mathrm{Zn}^{\mathrm{II}}\right)$-obtained complex in the solid state.

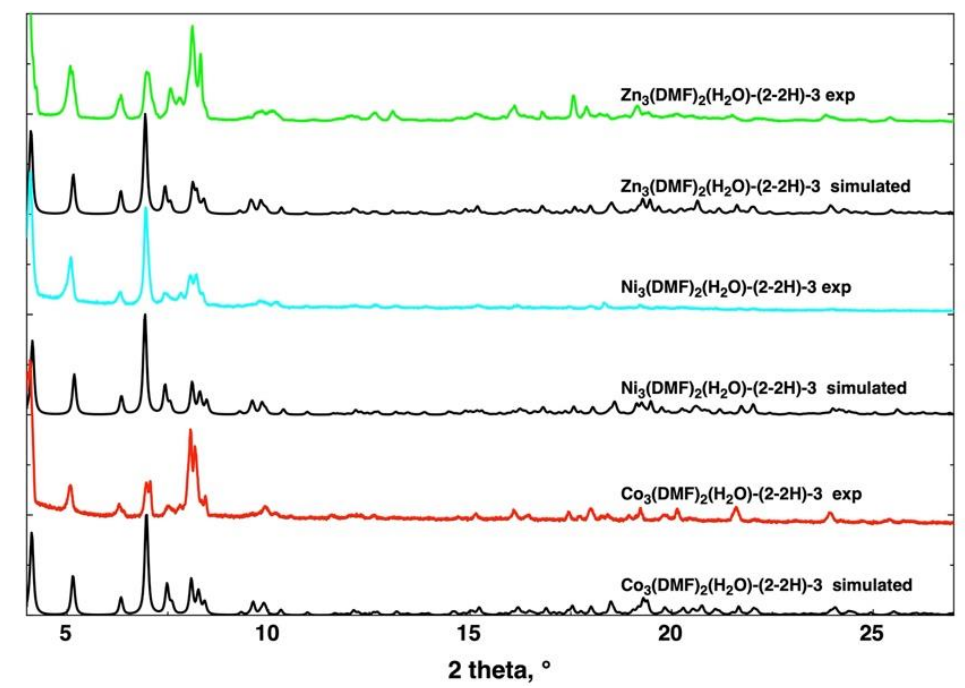

Figure 5. For $\mathrm{M}_{3}\left(\mathrm{H}_{2} \mathrm{O}\right)(\mathrm{DMF})_{2}-(2-2 \mathrm{H})-3\left(\mathrm{M}=\mathrm{Co}^{\mathrm{II}}\right.$ (red), $\mathrm{Ni}^{\mathrm{II}}$ (light blue) and $\mathrm{Zn}^{\mathrm{II}}$ (green)), comparison of the simulated and experimental powder X-Ray diffraction studies (PXRD) diagrams.

$\mathrm{M}_{3}(\mathrm{DMF})_{2}\left(\mathrm{H}_{2} \mathrm{O}\right)-(2-2 \mathrm{H})-3\left(\mathrm{M}=\mathrm{Co}^{\mathrm{II}}, \mathrm{Ni}^{\mathrm{II}}\right.$ and $\left.\mathrm{Zn}^{\mathrm{II}}\right)$ metallamacrocycles were obtained as pure trinuclear coordination compounds in the solid state, using solvothermal conditions followed by 
a slow evaporation of the solution. They represent unique examples of unsymmetrical trinuclear metallamacrocycles based on two different coordinating macrocycles, as schematically represented in Figure 6. The design of $(2-2 \mathrm{H})^{2-}$ is particularly well adapted to act as a "pincer" for the trinuclear coordination compound formed with $3^{4-}$, leading to the unique unsymmetrical and non-tubular shape of $\mathrm{M}_{3}(\mathrm{DMF})_{2}\left(\mathrm{H}_{2} \mathrm{O}\right)-(2-2 \mathrm{H})-3\left(\mathrm{M}=\mathrm{Co}^{\mathrm{II}}, \mathrm{Ni}^{\mathrm{II}}\right.$ and $\left.\mathrm{Zn}^{\mathrm{II}}\right)$.

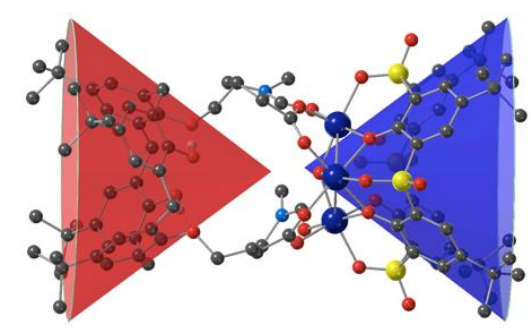

Figure 6. Schematic representation of the trinuclear complexes $\mathrm{M}_{3}\left(\mathrm{H}_{2} \mathrm{O}\right)(\mathrm{DMF})_{2}-(2-2 \mathrm{H})-3\left(\mathrm{M}=\mathrm{Co}{ }^{\mathrm{II}}\right.$, $\mathrm{Ni}^{\mathrm{II}}$ and $\left.\mathrm{Zn}{ }^{\mathrm{II}}\right)$ with $(2-2 \mathrm{H})^{2-}$ (red) and $3^{4-}$ (blue).

It is important to note that the metallic triangles, resulting from the association of two short and one long M-M bonds, are maintained by a $\mu_{3}-\mathrm{O}$ atom from a coordinated water molecule and are reproducibly obtained. This triangular feature has already been observed in the literature [45]. The observation of triangles with paramagnetic metallic ions is well documented [46,47], leading to high spin molecules presenting either ferromagnetic or antiferromagnetic interactions, depending on the geometric parameters.

This example represents the first example of controlled nuclearity for the formation of metallamacrocycles based on macrocyclic calixarene moieties. This opens the door to series of coordination compounds with tunable nuclearities associated with tunable encapsulation properties. Metallamacrocycles offer good alternatives for the formation of new coordination networks, can act as sensors, and can trap guest molecules, as presented here with DMF molecules.

\section{Conclusions}

In this work, the formation of the first example of new, unsymmetrical $\mathrm{M}_{3}\left(\mathrm{H}_{2} \mathrm{O}\right)(\mathrm{DMF})_{2}-(2-2 \mathrm{H})-3$ $\left(\mathrm{M}=\mathrm{Co}^{\mathrm{II}}, \mathrm{Ni}^{\mathrm{II}}\right.$ and $\left.\mathrm{Zn}^{\mathrm{II}}\right)$ metallamacrocycles involving two different calixarene ligands and a trinuclear $3 \mathrm{D}$ metallic cluster core has been demonstrated. It was established that the $(2-2 \mathrm{H})^{2-}$ calix[4]arene, decorated with two appended carboxylate moieties and a flexible alkyl spacer, is especially well designed for binding the trinuclear clusters supported on tetrasulfonylcalix[4]arene $3^{4-}$, leading to a easily reproducible recognition pattern, which may be used for the generation of new metallamacrocycles involving different types of dicarboxylic ligands based on the macrocyclic platform.

The study of the ability of tetrasulfonylcalix[4]arene $3^{4-}$ to form metallamacrocycles using its combination with other carboxylic derivatives of calix[4]arene in the presence of $d$ and $f$ metallic cations is currently in progress.

Author Contributions: Conceptualization: A.S.O., S.F., S.E.S., I.S.A.; Methodology: M.V.K., A.S.O.; formal analysis: M.V.K., D.R.I.; investigation: M.V.K., D.R.I.; data curation: D.R.I., A.I.S. and A.T.G.; writing-original draft preparation: S.F., A.S.O.; writing—review and editing: S.F., A.S.O.; supervision: A.S.O., S.E.S.; S.F.; I.S.A.; project administration: A.S.O.; S.E.S.; I.S.A.; funding acquisition: A.S.O., S.E.S., I.S.A.; all authors have read and agreed to the published version of the manuscript. All authors have read and agreed to the published version of the manuscript.

Funding: This research was funded by the Russian Science Foundation (grant number 19-73-20035).

Acknowledgments: The authors are grateful to the Spectral-Analytical Center of FRC Kazan Scientific Center of RAS for their help and support in the XRD experiments. Financial support from the University of Strasbourg, the Institut Universitaire de France and the CNRS are acknowledged. 
Conflicts of Interest: The authors declare no conflict of interest. The funders had no role in the design of the study; in the collection, analyses, or interpretation of data; in the writing of the manuscript, or in the decision to publish the results".

\section{References}

1. Yang, H.-B. Monograph in Supramolecular Chemistry: Metallomacrocycles: From Structures to Applications; The Royal Society of Chemistry: Cambridge, UK, 2017.

2. Saalfrank, R.W.; Stark, A.; Peters, K.; von Schnering, H.-G. The First “Adamantoid” Alkaline Earth Metal Chelate Complex: Synthesis, Structure, and Reactivity. Angew. Chem. Int. Ed. 1988, 27, 851-853. [CrossRef]

3. Guerriero, P.; Tamburini, S.; Vigato, P.A. From mononuclear to polynuclear macrocyclic or macroacyclic complexes. Coord. Chem. Rev. 1995, 139, 17-243. [CrossRef]

4. Leininger, S.; Olenyuk, B.; Stang, P.J. Self-Assembly of Discrete Cyclic Nanostructures Mediated by Transition Metals. Chem. Rev. 2000, 100, 853-907. [CrossRef]

5. Fujita, M. Self-Assembly of [2]Catenanes Containing Metals in Their Backbones. Acc. Chem. Res. 1999, 32, 53-61. [CrossRef]

6. Rojo, J.; Romero-Salguero, F.J.; Lehn, J.-M.; Baum, G.; Fenske, D. Self-Assembly, Structure, and Physical Properties of Tetranuclear $\mathrm{Zn}^{\mathrm{II}}$ and $\mathrm{Co}^{\mathrm{II}}$ Complexes of [2 $\times 2$ 2] Grid-Type. Eur. J. Inorg. Chem. 1999, 1999, 1421-1428. [CrossRef]

7. Song, J.; Moon, D.; Lah, M.S. Manganese Metallamacrocycles with Various Coordination Solvents. Bull. Korean Chem. Soc. 2002, 23, 708-714.

8. Lee, S.J.; Lin, W.B. Chiral Metallocycles: Rational Synthesis and Novel Applications. Acc. Chem. Res. 2008, 41, 521-537. [CrossRef]

9. El-Sayed, M.; Yuan, D. Metal-Organic Cages (MOCs): From Discrete to Cage-based Extended Architectures. Chem. Lett. 2020, 49, 28-53. [CrossRef]

10. Deiters, E.; Bulach, V.; Hosseini, M.W. Porphyrin based metallamacrocycles. New J. Chem. 2006, 30, $1289-1294$. [CrossRef]

11. Durot, S.; Flamigni, L.; Taesch, J.; Dang, T.T.; Heitz, V.; Ventura, B. Synthesis and Solution Studies of Silver(I)-Assembled Porphyrin Coordination Cages. Chem. Eur. J. 2014, 20, 9979-9990. [CrossRef]

12. Gutsche, C.D. Calixarenes Revised: Monographs in Supramolecular Chemistry; The Royal Society of Chemistry: Cambridge, UK, 1998; Volume 6.

13. Ikeda, A.; Shinkai, S. Novel Cavity Design Using Calix[n]arene Skeletons: Toward Molecular Recognition and Metal Binding. Chem. Rev. 1997, 97, 1713-1734. [CrossRef]

14. Kajiwara, T.; Iki, N.; Yamashita, M. Transition metal and lanthanide cluster complexes constructed with thiacalix[n]arene and its derivatives. Coord. Chem. Rev. 2007, 251, 1734-1746. [CrossRef]

15. Ovsyannikov, A.; Solovieva, S.; Antipin, I.; Ferlay, S. Coordination Polymers based on calixarene derivatives: Structures and properties. Coord. Chem. Rev. 2017, 352, 151-186. [CrossRef]

16. Taylor, S.M.; Karotsis, G.; McIntosh, R.D.; Kennedy, S.; Teat, S.J.; Beavers, C.M.; Wernsdorfer, W.; Piligkos, S.; Dalgarno, S.J.; Brechin, E.K. A Family of Calix[4]arene-Supported [ $\left.\mathrm{Mn}^{\mathrm{III}}{ }_{2} \mathrm{Mn}_{2}{ }_{2}\right]$ Clusters. Chem. Eur. J. 2011, 17, 7521-7530. [CrossRef]

17. Kajiwara, T.; Kobashi, T.; Shinagawa, R.; Ito, T.; Takaishi, S.; Yamashita, M.; Iki, N. Highly Symmetrical Tetranuclear Cluster Complexes Supported by p-tert-Butylsulfonylcalix[4]arene as a Cluster-Forming Ligand. Eur. J. Inorg. Chem. 2006, 2006, 1765-1770. [CrossRef]

18. Iki, N.; Kumagai, H.; Morohashi, N.; Ejima, K.; Hasegawa, M.; Miyanari, S.; Miyano, S. Selective oxidation of thiacalix[4]arenes to the sulfinyl- and sulfonylcalix[4]arenes and their coordination ability to metal ions. Tetrahedron Lett. 1998, 39, 7559-7562. [CrossRef]

19. Mislin, G.; Graf, E.; Hosseini, M.W.; De Cian, A. Sulfone-calixarenes: A new class of molecular building block. J. Chem. Soc. Chem. Commun. 1998, 1345-1346. [CrossRef]

20. Bi, Y.; Du, S.; Liao, W. Thiacalixarene-based nanoscale polyhedral coordination cages. Coord. Chem. Rev. 2014, 276, 61-72. [CrossRef] 
21. Lamouchi, M.; Jeanneau, E.; Novitchi, G.; Luneau, G.; Brioude, A.; Desroches, C. Polynuclear Complex Family of Cobalt(II)/Sulfonylcalixarene: One- Pot Synthesis of Cluster Salt $\left[\mathrm{Co}_{14}{ }^{\mathrm{II}}\right]^{+}\left[\mathrm{Co}_{4}{ }^{\mathrm{II}}\right]^{-}$and Field-Induced Slow Magnetic Relaxation in a Six-Coordinate Dinuclear Cobalt(II)/Sulfonylcalixarene Complex. Inorg. Chem. 2014, 53, 63-72. [CrossRef]

22. Du, S.; Hu, C.; Xiao, J.-C.; Tana, H.; Liao, W. A giant coordination cage based on sulfonylcalix[4]arenes. Chem. Commun. 2012, 48, 9177-9179. [CrossRef]

23. Xiong, K.; Jiang, F.; Gai, Y.; He, Z.; Yuan, D.; Chen, L.; Su, K.; Hong, M. Self-Assembly of Thiacalix[4]arene-Supported Nickel(II)/Cobalt(II) Complexes Sustained by in Situ Generated 5-Methyltetrazolate Ligand. Cryst. Growth. Des. 2012, 12, 3335-3341. [CrossRef]

24. Geng, D.; Han, X.; Bi, Y.; Qin, Y.; Li, Q.; Huang, L.; Zhou, K.; Song, L.; Zheng, Z. Merohedral icosahedral $\mathrm{M}_{48}\left(\mathrm{M} \frac{1}{4} \mathrm{Co}^{\mathrm{II}}, \mathrm{Ni}^{\mathrm{II}}\right)$ cage clusters supported by thiacalix[4]arene. Chem. Sci. 2018, 9, 8535-8541. [CrossRef] [PubMed]

25. Shi, C.; Chen, M.; Han, X.; Bi, Y.; Huang, L.; Zhou, K.; Zheng, Z. Thiacalix[4]arene-supported tetradecanuclear cobalt nanocage cluster as precursor to synthesize $\mathrm{CoO} / \mathrm{Co}_{9} \mathrm{~S}_{8} @ \mathrm{CN}$ composite for supercapacitor Application. Inorg. Chem. Front. 2018, 5, 1329-1335. [CrossRef]

26. Bi, Y.; Xu, G.; Liao, W.; Du, S.; Wang, X.; Deng, R.; Zhang, H.; Gao, S. Making a [Co 24$]$ metallamacrocycle from the shuttlecock-like tetranuclear cobalt-calixarene building blocks. Chem. Commun. 2010, 46, 6362-6364. [CrossRef]

27. Klein, C.; Graf, E.; Hosseini, M.W.; De Cian, A.; Kyritsakas, N. Design and Structural Analysis of Metallamacrocycles Based on Zinc Halides and a V-Shaped Bismonodentate Ligand of the Cyclophane Type. Eur. J. Inorg. Chem. 2003, 7, 1299-1302. [CrossRef]

28. Ehrhart, J.; Planeix, J.-M.; Kyritsakas-Gruber, N.; Hosseini, M.W. Synthesis and structural studies of metallamacrotricycles based on a metacyclophane in 1,3-alternate conformation bearing four imidazolyl units. Dalton Trans. 2009, 14, 2552-2557. [CrossRef]

29. Ehrhart, J.; Planeix, J.-M.; Kyritsakas-Gruber, N.; Hosseini, M.W. Molecular tectonics: Formation and structural studies on a 2-D directional coordination network based on a non-centric metacyclophane based tecton and zinc cation. Dalton Trans. 2010, 39, 2137-2146. [CrossRef]

30. Chernova, E.F.; Ovsyannikov, A.S.; Ferlay, S.; Solovieva, S.E.; Antipin, I.S.; Konovalov, A.I.; Kyritsakas, N.; Hosseini, M.W. Molecular tectonics: From a binuclear metallamacrocycle to a 1D isostructural coordination network based on tetracyanomethyl[1.1.1.1]metacyclophane and a silver cation. Mendeleev Commun. 2017, 27, 260-262. [CrossRef]

31. Lesińska, U.; Bocheńska, M. Lower-Rim-Substituted tert-Butylcalix[4]arenes; Part IX: One-Pot Synthesis of Calix[4]arene-Hydroxamates and Calix[4]arene-Amides. Synthesis 2006, 16, 2671-2676.

32. Hallale, O.; Bourne, S.A.; Koch, K.R. Metallamacrocyclic complexes of Ni(ii) with 3,3,3',3'tetraalkyl-1,1'-aroylbis(thioureas): Crystal and molecular structures of a 2:2 metallamacrocycle and a pyridine adduct of the analogous 3:3 complex. CrystEngComm 2005, 7, 161-166. [CrossRef]

33. Ferrer, M.; Gutierrez, A.; Mounir, M.; Rossell, O.; Ruiz, E.; Rang, A.; Engeser, M. Self-Assembly Reactions between the Cis-Protected Metal Corners (N-N)MII (N-N = Ethylenediamine, 4,4'-Substituted 2,2'-Bipyridine; $\mathrm{M}=\mathrm{Pd}, \mathrm{Pt}$ ) and the Fluorinated Edge 1,4-Bis(4-pyridyl)tetrafluorobenzene. Inorg. Chem. 2007, 46, 3395-3406. [CrossRef] [PubMed]

34. Burkill, H.A.; Robertson, N.; Vilar, R.; White, A.J.P.; Williams, D.J. Synthesis, Structural Characterization, and Magnetic Studies of Polynuclear Iron Complexes with a New Disubstituted Pyridine Ligand. Inorg. Chem. 2005, 44, 3337-3346. [CrossRef] [PubMed]

35. Granzhan, A.; Schouwey, C.; Riis-Johannessen, T.; Scopelliti, R.; Severin, K. Connection of Metallamacrocycles via Dynamic Covalent Chemistry: A Versatile Method for the Synthesis of Molecular Cages. J. Am. Chem. Soc. 2011, 133, 7106-7115. [CrossRef] [PubMed]

36. Shan, N.; Vickers, S.J.; Adams, H.; Ward, M.D.; Thomas, J.A. Switchable electron-transfer processes in a mixed-valence, kinetically locked, trinuclear Ru(II) metallamacrocycle. Angew. Chem. Int. Ed. 2004, 43, 3938-3941. [CrossRef] [PubMed]

37. Rouge, P.; Silva Pires, V.; Gaboriau, F.; Dassonville-Klimpt, A.; Guillon, J.; Da Nascimento, S.; Leger, J.-M.; Lescoat, G.; Sonnet, P. Antiproliferative effect on HepaRG cell cultures of new calix[4]arenes. J. Enz. Inhib. Med. Chem. 2010, 25, 216-227. [CrossRef] [PubMed] 
38. Hosseini, A.; Taylor, S.; Accorsi, G.; Armaroli, N.; Reed, C.A.; Boyd, P.D.W. Calix[4]arene-Linked Bisporphyrin Hosts for Fullerenes: Binding Strength, Solvation Effects, and Porphyrin-Fullerene Charge Transfer Bands. J. Am. Chem. Soc. 2006, 128, 15903-15913. [CrossRef]

39. Dolomanov, O.V.; Bourhis, L.J.; Gildea, R.J.; Howard, J.A.K.; Puschmann, H.J. OLEX2: A Complete Structure Solution, Refinement and Analysis Program. Appl. Cryst. 2009, 42, 339-341. [CrossRef]

40. Sheldrick, G.M. SHELXT: Integrating space group determination and structure solution. Acta Crystallogr. 2015, 71, 3-8. [CrossRef]

41. Sheldrick, G.M. A Short History of SHELX. Acta Crystallogr. 2007, 64, 112-122. [CrossRef]

42. Macrae, C.F.; Edgington, P.R.; McCabe, P.; Pidcock, E.; Shields, G.P.; Taylor, R.; Towler, M.; Van De Streek, J. Visualization and analysis of crystal structures. J. Appl. Crystallogr. 2006, 39, 453-457. [CrossRef]

43. Guzei, I.A. An idealized molecular geometry library for refinement of poorly behaved molecular fragments with constraints. J. Appl. Crystallogr. 2014, 47, 806-809. [CrossRef]

44. Available online: https://www.ccdc.cam.ac.uk/structures/ (accessed on 27 March 2020).

45. Wang, S.; Hang, X.; Zhu, X.; Han, H.; Zhang, G.; Liao, W. 1D morning glory-like calixarene-based coordination polymers as a support for Au/Ag nanoparticles. Polyhedron 2017, 130, 75-80. [CrossRef]

46. Katsenis, A.D.; Kessler, V.G.; Papaefstathiou, G.S. High-spin Ni(II) clusters: Triangles and planar tetranuclear complexes. Dalton Trans. 2011, 40, 4590-4598. [CrossRef] [PubMed]

47. Schmitz, S.; van Leusen, J.; Izarova, N.V.; Bourone, S.D.M.; Ellern, A.; Kögerler, P.; Monakhov, K.Y. Triangular $\left\{\mathrm{Ni}_{3}\right\}$ coordination cluster with a ferromagnetically coupled metal-ligand core. Polyhedron 2018, 144, $144-151$. [CrossRef]

(C) 2020 by the authors. Licensee MDPI, Basel, Switzerland. This article is an open access article distributed under the terms and conditions of the Creative Commons Attribution (CC BY) license (http://creativecommons.org/licenses/by/4.0/). 